\author{
ŁUKASZ STRZĘPEK \\ ORCID: 0000-0003-2292-7889 \\ Wyższa Szkoła „Humanitas” w Sosnowcu
}

\title{
TELEFONICZNE ZAŁATWIENIE SPRAWY ADMINISTRACYJNEJ
}

\begin{abstract}
Abstrakt: Możliwość telefonicznego załatwienia sprawy administracyjnej jest istotną nowością wśród przyjętych rozwiązań dotyczących procedury administracyjnej. Ustawodawca uznał tę kwestię za szczególnie istotną, opisując taką możliwość wśród zasad ogólnych k.p.a. W praktyce mogą się jednak pojawić problemy z zastosowaniem tego przepisu, zwłaszcza odnośnie do jego hipotezy, a także dokumentowania aktywności organu w tym zakresie. Niniejsze opracowanie jest zasygnalizowaniem najistotniejszych problemów, a zarazem wskazuje możliwości ich rozwiązania, jako przyczynek do dyskusji.
\end{abstract}

Słowa kluczowe: telefoniczne załatwienie sprawy, adnotacja urzędowa, kontakt ze stroną

\section{WPROWADZENIE}

Nowelizacje ustawy z dnia 14 czerwca 1960 roku Kodeks postępowania administracyjnego (dalej: k.p.a.) $)^{1}$ dokonane w 2017 roku i latach następnych ${ }^{2}$, w znaczący sposób zmieniły dotychczas obowiązującą procedurę administracyjną, wprowadzając szereg nowych, nieznanych wcześniej instytucji prawnych oraz rozwiązań normatywnych. Wśród dokonanych zmian poczesne miejsce zajmują te, które odnoszą się do zasad ogólnych k.p.a. Jedna z takich zmian dotknęła art. $14 \S 2$ k.p.a., w którym obecnie przewidziano możliwość telefonicznego załatwienia sprawy administracyjnej.

Wskazany przepis reguluje istotną $\mathrm{w}$ prawidłowym przebiegu postępowania administracyjnego zasadę pisemności, zaliczaną do zasad techniczno-

1 Tekst jedn. Dz.U. z 2020 r. poz. 256 (dalej: k.p.a.).

2 Ustawa z dnia 7 kwietnia 2017 roku o zmianie ustawy Kodeks postępowania administracyjnego oraz innych ustaw; art. $14 \S 2$ zmieniony został ustawą z dnia 6 marca 2018 roku — Przepisy wprowadzające ustawę Prawo przedsiębiorców oraz inne ustawy dotyczące działalności gospodarczej, Dz.U. poz. 650. 
-procesowych, zapewniających właściwy tok postępowania administracyjnego ${ }^{3}$. Jej podstawową funkcją jest zagwarantowanie prawidłowego utrwalenia czynności dokonywanych w trakcie postępowania, co umożliwia i ułatwia ewentualną kontrolę instancyjną lub sądową, a ponadto ułatwia zapoznanie się ze zgromadzonym materiałem dowodowym oraz argumentacją organu w akcie kończącym postępowanie. Ustawodawca dopuszcza rzecz jasna inne formy, co jest przedmiotem niniejszego opracowania, jednakże pisemność postępowania ma priorytetowe znaczenie, zwłaszcza ze względu na zapewnienie pewności obrotu prawnego.

$\mathrm{Na}$ tym tle wyjątek od tej zasady, jakim jest możliwość załatwienia sprawy drogą telefoniczną, jawi się jako niemal rewolucyjny krok na drodze do odformalizowania procedury administracyjnej.

Podkreślić jednocześnie trzeba, że art. $14 \S 2$ k.p.a. jest jedną z dwóch regulacji (oprócz art. $55 \S 1$ k.p.a.), która odnosi się do takiej formy nawiązania kontaktu ze stroną. Lakoniczność przyjętego przepisu, jego usytuowanie w kodeksie, wreszcie potencjalne konsekwencje zastosowania uzasadniają bliższe przyjrzenie się temu rozwiązaniu, a także podjęcie próby oceny jego przydatności względem pozostałych rozwiązań normatywnych.

Nie pretendując, ze względu na tematykę i charakter opracowania, do szczegółowego omówienia zasad ogólnych k.p.a., nie da się uniknąć poczynienia kilku spostrzeżeń na temat ich istoty, co z kolei pozwoli spojrzeć na omawiane zagadnienie z szerszej perspektywy.

\section{ZASADY OGÓLNE KODEKSU POSTĘPOWANIA ADMINISTRACYJNEGO — UWAGI WPROWADZAJĄCE}

Przepis art. $14 \S 2$ k.p.a., przewidujący możliwość telefonicznego załatwienia sprawy administracyjnej, znajduje się wśród regulacji zawartych w drugim rozdziale działu I k.p.a. Jego usytuowanie wskazuje na rolę, jaką ustawodawca przewidział dla grupy przepisów nazwanych zasadami ogólnymi. Poza sporem pozostaje ich funkcja, którą można, cytując jednego z autorów, sprowadzić do fundamentu postępowania ${ }^{4}$. Zarazem, co trzeba stanowczo podkreślić, charakter prawny zasad ogólnych nie sprowadza ich do roli instrukcji bądź też zaleceń kierowanych do organów administracji ${ }^{5}$, lecz przede wszystkim wymaga traktowania ich jako norm prawnych o szczególnym, nadrzędnym charakterze. Niewątpliwie regulacje

3 Por. B. Adamiak, J. Borkowski, Postępowanie administracyjne i sadowoadministracyjne, Warszawa 2014, s. 45.

4 Tak P. Krzykowski, Funkcje zasad ogólnych Kodeksu postęowania administracyjnego, [w:] Kodyfikacja postępowania administracyjnego na 50-lecie KPA, red. J. Niczyporuk, Lublin 2010, s. 439.

5 Por. S. Rozmaryn, O zasadach ogólnych kodeksu postepowania administracyjnego, PiP 1959, nr 4, s. 89. 
rozdziału 2 k.p.a. należy zaliczyć, nie tylko z powodu ich systemowego usytuowania, do szczególnego typu norm, a mianowicie zasad prawa, które zarówno w doktrynie, jak i w judykaturze stanowią jedno z najbardziej złożonych i jednocześnie spornych zjawisk ${ }^{6}$. O stopniu komplikacji związanych nie tylko z ich stosowaniem, lecz także z opisem, świadczy daleko idąca rozbieżność poglądów w tej materii. Wskazać bowiem trzeba, że jedni autorzy twierdzą, iż zasady te nie są konkretnymi przepisami prawa, lecz stanowią zgeneralizowaną treść zespołu norm, choć poszczególne przepisy prawne mogą w sposób względnie ścisły reprezentować treść poszczególnych zasad ogólnych ${ }^{7}$. Z tego punktu widzenia zasady prawne, a więc również te zawarte w k.p.a., są wynikiem wnioskowania opartego na wielu normach, które mają pewne cechy wspólne. To spostrzeżenie nie dotyczy rzecz jasna tych, których treść wynika wprost z przepisów prawa, częstokroć zamieszczanych na początku aktu prawnego. W doktrynie najdalej idący w tym względzie pogląd sformułował W. Dawidowicz, który zaproponował podział na ,zasady normatywne" i ,normy zasady"8. Pierwsza grupa to takie, które zostały wyprowadzone z szeregu norm, ale nie zostały wyrażone w nich expressis verbis. Drugie natomiast to zasady bezpośrednio wyartykułowane w konkretnych przepisach.

Odnotować trzeba jednak istnienie odmiennego stanowiska, zgodnie z którym nie uznawano zasad za normy prawne, traktując je jako postulaty9 ${ }^{9}$ W ocenie autora tej koncepcji we współczesnym mu stanie prawnym nie istniały normy o zasadniczym znaczeniu dla pozostałych regulacji. Co istotne, nie wykluczał z góry możliwości stworzenia tego rodzaju norm w przyszłości. Zasadnicze zastrzeżenie odnosiło się do wyinterpretowania zasady ogólnej z różnych przepisów. Zawsze istnieje bowiem niebezpieczeństwo rozdźwięku między wynikiem interpretacji a obowiązującymi poglądami na rolę danej instytucji wśród przepisów.

Poczynione uwagi świadczą o tym, że analizy zagadnienia zasad prawa nie ułatwia ich przynależność do norm, które podlegają zmianom związanym zarówno ze światem zewnętrznym (zmiany polityczno-ustrojowe, wstąpienie kraju do określonych wspólnot międzynarodowych), lecz również wewnętrznym (związanym $z$ systemem prawnym przyjętym na gruncie określonego państwa) - mającym związek z aksjologią ${ }^{10}$. Zasady prawa cechuje swoiste „niedomknięcie pojęciowe", które stwarza daleko większą możliwość ich interpretacji aniżeli w wypadku ,zwykłych” przepisów. Niejednoznaczność używanych w nich pojęć

${ }^{6}$ Por. L. Leszczyński, Zasady prawa - założenia podstawowe, [w:] Zasady prawa w strukturze systemu prawa. Studium dogmatyczno-porównawcze, red. L. Leszczyński, („Studia Iuridica Lublinensis" nr 1), Lublin 2016, s. 13.

7 Tak J. Starościak, Studia z teorii prawa administracyjnego, Wrocław 1967, s. 93 n.

8 W. Dawidowicz, Nauka prawa administracyjnego. Zarys wykładu, t. 1, Warszawa 1965, s. 142.

9 A. Jaroszyński, Wpływ przeksztatceń administracji socjalistycznej na pozycje prawna obywatela, Warszawa 1977, s. 74 n.

10 L. Leszczyński, G. Maroń, Zasady prawa. Ujęcie dogmatyczno-porównawcze, [w:] Zasady prawa $w$ strukturze..., s. 319 . 
sprawia, że stosowanie najczęstszej wykładni językowej nie daje satysfakcjonujących rezultatów i wymagane jest sięganie do innych metod. Tu niejednokrotnie pierwszoplanową rolę odgrywa wykładnia celowościowa lub systemowa, dająca zarazem szerokie pole do popisu organom lub sądom.

Prezentowane stanowiska dotyczące zasad prawa nie wyczerpują rzecz jasna spektrum poglądów zawartych w doktrynie. Wypada zauważyć, że ogólnie panuje konsensus odnośnie do posługiwania się tym pojęciem zarówno co do konkretnych norm prawnych, jak i wyników interpretacji całej grupy norm ${ }^{11}$. Na tym tle art. $14 \S 2$ k.p.a. traktować należy jako zasadę-regułę mającą zdecydowanie „techniczny" charakter. Jest to bowiem regulacja odnosząca się do tych aspektów postępowania, które wiążą się z jego prawidłowym (płynnym) przebiegiem — stąd też wniosek, że omawiany przepis ma charakter regulacyjny, nie zaś normatywny, w tym znaczeniu, że odnosi się on nie tyle do praw i obowiązków stron postępowania, ile do powinności oraz możliwości przeprowadzania czynności przez organ w określonej formie. Oczywiste jest przy tym, że przyjęcie określonej formy załatwienia sprawy nie jest obojętne dla stron i może wywoływać określone konsekwencje procesowe. Niemniej jednak stwierdzić wypada, że zasada ta ma przede wszystkim znaczenie stricte proceduralne i w mniejszym stopniu aniżeli pozostałe wpływa na wynik postępowania.

\section{FORMY ZAŁATWIENIA SPRAWY ADMINISTRACYJNEJ}

W analizowanym przepisie art. 14 k.p.a. ustawodawca trzykrotnie posługuje się zwrotem ,załatwienie sprawy administracyjnej”, odnosząc go do poszczególnych form, w jakich organ może to zrobić. W § 1 wskazanego przepisu ustanowiono ogólną regułę, zgodnie z którą sprawy administracyjne powinny być załatwiane (ustawodawca użył sformułowania „,należy załatwiać”) w formie pisemnej lub w formie dokumentu elektronicznego w rozumieniu przepisów ustawy z dnia 17 lutego 2005 roku o informatyzacji podmiotów realizujących zadania publicz$\mathrm{ne}^{12}$. W $\S 2$ przepisu wskazano $\mathrm{z}$ kolei alternatywne formy załatwienia sprawy administracyjnej, precyzując, że może to również nastąpić w formie ustnej, telefonicznej oraz za pomocą środków komunikacji elektronicznej w rozumieniu art. 2 pkt 5 ustawy z dnia 18 lipca 2002 roku o świadczeniu usług drogą elektroniczną ${ }^{13}$.

Kwestią, którą wypada rozważyć najpierw, jest pojęcie załatwienia sprawy administracyjnej, gdyż przyjęcie określonego rozumienia tego zwrotu determi-

11 Tak między innymi Z. Kmieciak, Ogólne zasady prawa i postępowania administracyjnego, Warszawa 2000, s. 37 n.; A Wiktorowska, Zasady ogólne KPA, OMT 1979, nr 4, s. 36 n.

12 Tekst jedn. Dz.U. z 2020 r. poz. 346.

13 Tekst jedn. Dz.U. z 2020 r. poz. 344. 
nować będzie zrozumienie intencji ustawodawcy przewidującego kilka różnych metod działania organu administracji w prowadzonym postępowaniu.

Użyte przez ustawodawcę sformułowanie ,załatwienie sprawy” może być rozumiane na co najmniej dwa sposoby. Pierwszy z nich można traktować jako węższy, albowiem wiąże się on z odwołaniem do innego przepisu kodeksu, a mianowicie art. $104 \S 1$ k.p.a. Regulacja ta wprost wskazuje, że organ administracji publicznej załatwia sprawę przez wydanie decyzji administracyjnej, chyba że przepisy kodeksu stanowią inaczej. Nie da się nie dostrzec związku między art. 14 k.p.a. a art.104 § 1 k.p.a., jednakże uściślenia wymaga ich wzajemna relacja.

W literaturze przyjmuje się, że art. $104 \S 1$ k.p.a. stanowi ,procesowe określenie decyzji administracyjnej jako formy załatwienia sprawy — przez jej rozstrzygnięcie co do istoty lub zakończenie sprawy w danej instancji w inny sposób"14. Przepis ów stanowi dla organów prowadzących postępowanie wskazówkę co do formy, w jakiej powinno nastąpić jego zakończenie. Jednocześnie można z jego treści wywnioskować, że pod pojęciem załatwienia sprawy ustawodawca w tym przypadku rozumie wydanie rozstrzygnięcia tworzącego, znoszącego lub kształtującego stosunek materialnoprawny, ewentualnie kończącego postępowanie administracyjne przez jego umorzenie. Owo załatwienie sprawy jest więc finalnym etapem postępowania, w którym organ daje wyraz swojej woli, przy czym jest to wola ukształtowana $z$ jednej strony przepisami prawa materialnego i procesowego wiążącymi organ, $\mathrm{z}$ drugiej natomiast ustaleniami poczynionymi $\mathrm{w}$ toku prowadzonego postępowania. Samo załatwienie sprawy wiąże się z zakomunikowaniem stronom treści wydanego rozstrzygnięcia. W takim ujęciu art. 14 k.p.a. wiązałby się $\mathrm{z}$ formami, w jakich komunikacja ta może nastąpić.

Można też założyć, że pojęcie ,załatwienie sprawy” obejmuje wiele działań organu, których wynikiem jest wydanie przez organ rozstrzygnięcia kończącego postępowanie w danej instancji. Przy takim założeniu analizowany zwrot nie ograniczałby się wyłącznie do finalnego wyniku postępowania, lecz obejmowałby wszystkie czynności związane z jego tokiem ${ }^{15}$.

Sam zwrot ,załatwienie sprawy” nie został w ustawie zdefiniowany, natomiast pojawia się w różnych przepisach. Począwszy od art. 7 k.p.a., w którym na organ nałożony został obowiązek podjęcia wszelkich czynności niezbędnych do dokładnego wyjaśnienia stanu faktycznego oraz załatwienia sprawy, przez

14 Kodeks postępowania administracyjnego. Komentarz, red. Z. Kmieciak, W. Chróścielewski, Warszawa 2019, s. 594.

15 Ibidem s. 125. Autorzy precyzują, że w świetle omawianego przepisu chodzi o utrwalenie wszystkich, istotnych dla sprawy lub toku postępowania czynności. Zgodnie z innym poglądem, którego nie podzielam, pojęcie załatwienia sprawy obejmuje nie tylko czynność kończącą tok postępowania, a więc wydanie decyzji, lecz także inne czynności procesowe podejmowane od wszczęcia postępowania do jego zakończenia; por. R. Kędziora, Kodeks postępowania administracyjnego. Komentarz, Warszawa 2014, s. 142. Podobnie Kodeks postępowania administracyjnego. Komentarz, red. H. Knysiak-Molczyk, Warszawa 2015, s. 104. 
inne zasady ogólne (na przykład zasadę tłumaczenia przesłanek — art. 11, zasadę szybkości - art. 12 czy zasadę polubownego rozstrzygania kwestii spornych art. $13 \S 2$ k.p.a.), regulacje dotyczące wyłączenia pracownika organu, terminów załatwienia sprawy aż do mediacji i milczącego załatwienia sprawy. Zważywszy na treść wskazanych przepisów, a zwłaszcza stwierdzenie, że organy mają podejmować wszelkie czynności niezbędne do dokładnego wyjaśnienia stanu faktycznego i załatwienia sprawy (art. 7 k.p.a.), założyć można, że chodzi tu o wszelkie czynności związane z doprowadzeniem postępowania do finału. Odnotować bowiem wypada, że kodeks postępowania administracyjnego rozgranicza załatwienie sprawy od jej rozstrzygnięcia (por. tytułem przykładu: art. 1 pkt 1 k.p.a., art. 67 $\S 1$, art. $107 \S 1$ pkt 5 k.p.a.). Rozstrzygnięcie sprawy oznacza ustalenie, ograniczenie lub odebranie prawa bądź też nałożenie na stronę obowiązku, ewentualnie umorzenie postępowania ${ }^{16}$. Jest to $\mathrm{w}$ istocie rezultat stosowania normy prawa materialnego do konkretnego przypadku w kontekście określonych okoliczności faktycznych i materiału dowodowego, samo rozstrzygnięcie zaś, jako element decyzji, przedstawia sposób zakończenia postępowania w danej instancji ${ }^{17}$. Wobec tego wydaje się, że nie można postawić znaku równości między „,załatwieniem” sprawy a jej ,rozstrzygnięciem”. Przy uwzględnieniu poczynionych uwag można założyć, że załatwianie sprawy wiąże się z podejmowaniem konkretnych działań, pozwalających na zdobycie wiedzy wystarczającej do uzyskania obiektywnie pełnego obrazu sytuacji (faktycznej i prawnej) i dokonania wyboru rozstrzygnięcia, optymalnego z punktu widzenia zarówno przepisów prawa materialnego oraz procesowego, jak i wyważenia interesu społecznego i słusznego interesu obywateli. Konsekwencją takiego punktu widzenia jest wykluczenie możliwości telefonicznego wydania (zakomunikowania treści) decyzji administracyjnej, albowiem na przeszkodzie stoi nie tylko wskazane wcześniej rozróżnienie między załatwieniem sprawy a jej rozstrzygnięciem, lecz przede wszystkim treść przepisów szczególnych — konkretnie zaś art. $67 \S 2$ pkt 5 k.p.a.

\section{STOPNIOWANIE FORM ZAŁATWIENIA SPRAWY ADMINISTRACYJNEJ}

Przepis art. $14 \S 1$ k.p.a. wprost stanowi, że sprawy należy załatwiać w formie pisemnej lub $\mathrm{w}$ formie dokumentu elektronicznego w rozumieniu przepisów ustawy o informatyzacji działalności podmiotów realizujących zadania publiczne. Ustawodawca, w niebudzący wątpliwości sposób, dał do zrozumienia, że prefero-

16 Por. Kodeks postępowania administracyjnego..., red. H. Knysiak-Molczyk, s. 739.

17 Por. wyrok WSA w Białymstoku z dnia 16 stycznia 2020 r., II SA/Bk 719/10; wyrok WSA w Kielcach z dnia 9 lipca 2020 r., I SA/Ke 166/20; wyrok WSA w Rzeszowie z dnia 17 lipca 2019 r., II SA/Rz 544/19 — wszystkie wyroki sądów administracyjnych powołane w tekście zob. www.nsa. gov.pl/orzeczenia. 
waną formą dokonywania czynności w postępowaniu jest forma pisemna, ewentualnie elektroniczna. Zastrzec przy tym jednak trzeba, że posłużenie się sformułowaniem „należy” ab initio pozwala zastanowić się, czy w pewnych określonych sytuacjach, niejako alternatywnie, organ może korzystać z innych form przewidzianych $w$ \& 2 cytowanych regulacji.

Konstrukcja tego przepisu, jak również semantyczne znaczenie użytych w nim sformułowań pozwalają przyjąć, że forma pisemna jest podstawową metodą dokumentowania przebiegu postępowania, komunikacji ze stroną oraz wydawania rozstrzygnięć. Jest to zresztą stan istniejący od samego wejścia w życie kodeksu. Nieco mylące może być rzecz jasna użycie słowa „należy”, co mogłoby sugerować pewien zakres swobody organu w tym zakresie. Tymczasem sformułowanie to wypada traktować jako obowiązek organu prowadzenia postępowania $\mathrm{w}$ formie pisemnej.

$\mathrm{Na}$ równi z formą pisemną ustawodawca dopuścił możliwość korzystania przez organ $\mathrm{z}$ komunikacji elektronicznej - w formie dokumentu elektronicznego. Skorzystanie z tej możliwości wymaga jednak spełnienia pewnych warunków, bez których nie jest to możliwe, a całe postępowanie przybiera formę podstawową — pisemną. Regulację art. $14 \S 1$ k.p.a. w zakresie, w jakim dopuszcza ona załatwienie sprawy $\mathrm{w}$ formie dokumentu elektronicznego, należy odczytywać łącznie z przepisami rozdziału 8 k.p.a., a konkretnie z art. 391 . Przepis ów wskazuje przesłanki doręczania pism drogą elektroniczną. $Z$ jego treści wywnioskować można, że jest to możliwe tylko wtedy, gdy strona sama wykaże w tym względzie inicjatywę (art. $39^{1} \S 1$ pkt 1 i 2) bądź też gdy wyrazi zgodę na doręczanie pism w taki sposób (art. $39^{1} \S 1$ pkt 3). Zarazem stronie lub innemu uczestnikowi postępowania przysługuje uprawnienie do zrezygnowania z doręczania pism za pomocą środków komunikacji elektronicznej, czego następstwem jest doręczanie pism w sposób inny aniżeli forma dokumentu elektronicznego (art. $39^{1} \S 1$ d k.p.a.), w sposób określony dla pisma — czyli w „zwykłej” formie pisemnej.

Jak już wspomniano, art. $14 \S 2$ k.p.a. przewiduje alternatywne, jeżeli chodzi o formę podejmowanych czynności, metody załatwienia sprawy administracyjnej. Kodeks jako pierwsze wskazuje ustne załatwienie sprawy, telefoniczne, za pomocą środków komunikacji elektronicznej w rozumieniu art. 2 pkt 5 ustawy o świadczeniu usług drogą elektroniczną lub za pomocą innych środków łączności, gdy przemawia za tym interes strony, a przepis prawny nie stoi temu na przeszkodzie. Takie brzmienie przepisu daje podstawy do stwierdzenia, że wszystkie wymienione w niej formy załatwienia sprawy mają charakter alternatywny względem siebie, a ich wybór uzależniony jest od nieistnienia wyraźnego przepisu wymagającego zastosowania konkretnej formy oraz od istnienia interesu strony w komunikacji $\mathrm{z}$ organem tą drogą. Co więcej, wydaje się, że ze względu na potrzeby toczącego się postępowania działania organu i strony zmierzające do ,załatwienia sprawy" mogą przybierać różne postacie, w zależności od potrzeb oraz skuteczności w dążeniu do zakończenia postępowania. Mogą rzecz jasna pojawić się trudno- 
ści w ustaleniu, czy przyjęcie określonej formy czynności odpowiada interesowi strony. W zależności od okoliczności organ może wówczas albo upewnić się co do tego, uzyskując oświadczenie strony, albo też, mając na względzie pozostałe zasady ogólne postępowania (na przykład art. 10 lub art. $12 \S 1$ k.p.a.), wybrać optymalną w jego założeniu formę. W tym ostatnim przypadku istnieje oczywiście ryzyko, że wybór organu nie będzie zbieżny z interesem strony, niemniej jednak, o ile będzie to możliwe, czynność będzie mogła być powtórzona, ewentualnie strona zapoznana zostanie z jej rezultatem.

Pozostawiając na uboczu szczegółowe kwestie dotyczące poszczególnych form załatwiania sprawy, pamiętając o temacie opracowania, wypada skoncentrować się na formie telefonicznej.

Ustawodawca o działaniach organu $\mathrm{w}$ formie telefonicznej wypowiada się w kodeksie w dwóch przepisach. Pierwszym z nich jest omawiany art. 14 § 2 k.p.a, drugim natomiast art. $55 \S 1$, zgodnie z którym w sprawach niecierpiących zwłoki wezwania można dokonać również telefonicznie albo przy użyciu innych środków łączności. Lektura obydwu tych przepisów potwierdza to, co zostało już wcześniej powiedziane, a mianowicie że telefoniczne załatwienie sprawy jest swoistą alternatywą dla pisemnej formy. Rozważenia wymaga wobec tego kwestia, czy forma telefoniczna zawsze może być stosowana zamiennie względem formy pisemnej lub dokumentu elektronicznego, czy też, poza przesłankami wskazanymi w $\S 2$ art. 14 k.p.a., istnieją jeszcze inne okoliczności warunkujące $\mathrm{z}$ niej skorzystanie. $\mathrm{Z}$ treści art. $14 \S 2$ k.p.a. wynika, że skorzystanie z telefonicznej możliwości załatwienia sprawy wymaga kumulatywnego spełnienia dwóch przesłanek: musi przemawiać za tym interes strony oraz to, że nie ma przepisu stojącego temu na przeszkodzie. O ile ta druga przesłanka jest oczywista, gdyż w samym kodeksie istnieje wiele przepisów wprost mówiących o tym, w jakiej formie dana czynność (materialno-techniczna lub procesowa) ma nastąpić ${ }^{18}$, o tyle kwestią sporną może być ustalenie, czy i w jakim stopniu organ jest władny oceniać kwestie dotyczące interesu strony.

W orzecznictwie był prezentowany, i nadal funkcjonuje, pogląd, że organ nie jest władny wnikać i badać, co jest działaniem zgodnym $\mathrm{z}$ interesem strony, a co nie, gdyż to sama strona ma wyłączną kompetencję do decydowania w tym zakresie. Jest to stanowisko niewątpliwie trafne, tyle że formułowanie tak jednoznacznego wniosku w odniesieniu do komentowanego przepisu wydaje się niezgodne z intencją ustawodawcy. Bez wątpienia można wyobrazić sobie sytuację, w której strona, ze względu na swoją nieporadność, niedostatek wiedzy, czasu lub możliwości, mogłaby ponieść szkodę, o ile organ nie mógłby odpowiednio szybko zareagować. Istota omawianej regulacji sprowadza się więc do stworzenia organowi możliwości elastycznego reagowania na okoliczności, które z perspektywy strony mogą pociągać dla niej negatywne konsekwencje. Można oczywiście zgłaszać

18 Por. art. $33 \S 2$ k.p.a, art. $49 \S 1$ k.p.a., art. $57 \S 5$ k.p.a., art. $67 \S 1$ k.p.a., art. $91 \S 2$ k.p.a. 
zastrzeżenia przeciwko takiej interpretacji, podnosząc, że przecież nierzadko interesy strony i organu (a konkretnie interesu publicznego lub społecznego, który organ reprezentuje) są względem siebie przeciwstawne, a tym samym trudno organowi, niejako wbrew sobie, ochraniać interes strony. Tu jednak wypada się odwołać do treści art. 7 k.p.a., nakazującego wyważać interes społeczny oraz słuszny interes obywateli. Wydaje się, że do kategorii słusznego interesu obywateli można zaliczyć takie działanie organu, który korzystając z dostępnych mu środków, nawiązuje komunikację ze stroną bądź też innymi podmiotami biorącymi udział w postępowaniu i zmierza do jego zakończenia w rozsądnym (a przynajmniej przewidzianym przepisami) terminie. Do kategorii obywateli można zaliczyć niewątpliwie strony postępowania, których interes uzasadnia skorzystanie z możliwości komunikacji telefonicznej. Jednocześnie działania bądź też zaniechania oparte na założeniu przeciwstawności interesów (społecznego, którego reprezentantem jest organ i indywidualnego - strony) przeczyłyby kodeksowej zasadzie prowadzenia postępowania w sposób budzący zaufanie jego uczestników do władzy publicznej (art. 8 k.p.a.). Z tego punktu widzenia organ, w miarę swoich możliwości, winien monitorować sytuację strony $\mathrm{i} w$ razie potrzeby, o ile istnieje zagrożenie niekorzystnych zmian w tym zakresie, korzystać z telefonicznej formy komunikacji.

Skorzystanie z komunikacji telefonicznej może być też traktowane jako jeden $\mathrm{z}$ aspektów zasady szybkości postępowania (art. $12 \S 1$ k.p.a.). Poza sporem pozostaje bowiem twierdzenie, że komunikacja telefoniczna może być obecnie uznana za najszybszą i jedną z najbardziej bezpośrednich form wymiany informacji między podmiotami biorącymi udział w postępowaniu. Toteż jeśli spełnione są warunki określone w art. $14 \S 2$ k.p.a., wówczas jest to niewątpliwie jeden $\mathrm{z}$ istotnych czynników pozwalających na sprawne prowadzenie postępowania. Również drugi z aspektów wymienionych $\mathrm{w}$ art. $12 \S 1$ k.p.a., a więc stosowanie najprostszych środków prowadzących do jej załatwienia, odnosi się bezpośrednio do korzystania $\mathrm{z}$ telefonicznej komunikacji z podmiotami biorącymi udział W postępowaniu. W szczególności zaś może tu chodzić o działania zmierzające do uzyskania informacji pozwalających na ustalenie istotnych dla wyniku postępowania okoliczności.

\section{ZAKRES CZYNNOŚCI MOŻLIWYCH DO ZAŁATWIENIA DROGĄ TELEFONICZNĄ}

Lektura art. $14 \S 2$ k.p.a. i pozostałych przepisów kodeksu skłania do refleksji nad katalogiem działań, które organ prowadzący postępowanie może załatwić drogą telefoniczną. Wydaje się bowiem, że teza, iż wszelkie czynności, które można określić mianem „załatwienia sprawy”, mogą być dokonywane telefonicznie, jest zbyt daleko idąca, a zarazem nie oddaje intencji ustawodawcy. 
Jeżeli przyjmie się założenie, że pojęcie załatwienia sprawy obejmuje swoim zakresem wszelką aktywność organu w postępowaniu, to niewątpliwie, poza przypadkami, co do których formę narzuca przepis, możliwe jest skorzystanie z możliwości telefonicznego kontaktu ze stroną (lub innym podmiotem), łącznie $\mathrm{z}$ zawiadomieniem o wszczęciu postępowania oraz z zakomunikowaniem treści decyzji w tej formie. Jedynym problemem byłaby wówczas kwestia znalezienia uzasadnienia dla tej formy komunikacji w odniesieniu do interesu strony. Tu zresztą wypada zauważyć, że ustawodawca nie sprecyzował, jaki interes miał na myśli. W grę wchodzi więc zarówno interes prawny, jak i interes faktyczny. Wydaje się jednak, że stosunkowo trudno znaleźć argumenty, które dawałyby podstawę do przyjęcia tezy, że organ, chcąc korzystać z telefonicznej formy komunikacji ze stroną, byłby uprawniony do badania jej interesu prawnego w tym kontekście. $\mathrm{W}$ kodeksie nie zdefiniowano bowiem interesu prawnego, czyniąc zeń atrybut uzyskania statusu strony - art. 28 k.p.a. Tu jednak należy stanowczo podkreślić, że sam przepis art. 28 k.p.a. nie tworzy podstawy do uznania kogoś za stronę, lecz jedynie wskazuje przymiot (cechę), która takiemu podmiotowi powinna być przypisana. W orzecznictwie istnieje ugruntowany pogląd, zgodnie z którym źródła interesu prawnego należy poszukiwać wśród przepisów prawa materialnego ${ }^{19}$. Brakuje też definicji interesu faktycznego, oznaczającego stan, w którym konkretny podmiot będzie dotknięty konsekwencjami rozstrzygnięcia administracyjnego, jednakże nielegitymujący się interesem prawnym w opisywanym wcześniej rozumieniu. Skoro zaś w art. $14 \S 2$ k.p.a. ustawodawca posłużył się pojęciem strony, to oczywiste jest, że przede wszystkim może chodzić o interes prawny. Kwestią wymagającą refleksji jest natomiast ustalenie, czy samo istnienie tego interesu byłoby okolicznością wystarczającą do skorzystania z tego przepisu, czy też interes ów winien być poddany dalszej analizie pod względem określonych kryteriów, a jeżeli tak, to jakich? Odpowiedzi na te pytania nie udziela żaden przepis kodeksu, a to oznacza, że trudno oczekiwać, że organ prowadzący postępowanie miałby dokonywać oceny interesu prawnego strony pod względem możliwości skorzystania z telefonicznej formy komunikacji. Nie ma też podstaw do przyjęcia założenia, że w tej materii, jakikolwiek przepis prawa materialnego, z którego byłby wywodzony interes prawny, mógłby stanowić podstawę działań organu w omawianym zakresie. Stąd wniosek, że przesłanką zastosowania art. 14 $\S 2$ k.p.a. jest w istocie interes faktyczny, a więc sytuacja, w której strona może ponieść negatywne konsekwencje braku sprawnego (szybkiego) kontaktu z organem, a zarazem owe ewentualne następstwa nie są przedmiotem prowadzonego postępowania administracyjnego, czyli nie można tu mówić o interesie prawnym.

19 Por. wyrok NSA z dnia 19 stycznia 1995 r., I SA 1326/93; oraz glosę do niego autorstwa I. Lipowicz i A. Agopszowicza, „Glosa” 1996, nr 1; wyrok WSA w Warszawie z dnia 29 marca 2006 r., VI SA/Wa 2401/05; uchwała siedmiu sędziów NSA z dnia 5 grudnia 2011 r., II OPS 1/11, ONSAiWSA 2012, nr 2. 
Przytoczone uwagi pozwalają stwierdzić, że interes, o którym mowa w art. 14 $\S 2$ k.p.a., ma charakter faktyczny, a więc dotyka obszarów istotnych dla strony, niemających jednakże ,zakotwiczenia” w przepisach prawa materialnego będących normatywną podstawą prowadzonego postępowania. Interes ów można, jak się wydaje, rozpatrywać w aspekcie procesowym. Tego rodzaju przypadkiem będzie na przykład kwestia upływu czasu, czyli sytuacja, w której stronie zależy na jak najszybszym zakończeniu postępowania. Wówczas organ może wezwać stronę do uzupełnienia braku formalnego wniosku właśnie drogą telefoniczną, celem ograniczenia do niezbędnego minimum formalności mogących wydłużyć postępowanie. Możliwe jest też ocenianie owego interesu w ujęciu materialnym, w którym konieczność niezwłocznej komunikacji ze stroną może wynikać z okoliczności niebędących w bezpośrednim związku z przedmiotem postępowania, na przykład zagrożenia utraty płynności finansowej lub środków przyznanych z funduszy europejskich, zwłaszcza gdy od wyniku postepowania zależeć będzie sytuacja strony w tych przypadkach. Przykłady tego rodzaju można by mnożyć. Świadczy to jednak o tym, że zmiana formy komunikacji między organem a stroną najczęściej podyktowana będzie chęcią nadania postępowaniu dynamiki niezbędnej z punktu widzenia strony. Zarazem pamiętać trzeba, że organ, oceniając przesłanki skorzystania $\mathrm{z}$ art. $14 \S 2$ k.p.a., nie może opierać się na własnym przeczuciu lub przekonaniu, lecz na faktach uprawdopodabniających istnienie takiego interesu strony. Innymi słowy, co już zresztą zostało podkreślone, jest to wyjątek od reguły, co oznacza, że muszą istnieć wyraźne przesłanki umożliwiające skorzystanie z niego.

Wracając do wątku czynności bądź też działań organu, które mogą być załatwione $\mathrm{w}$ formie telefonicznej, uważam, że ustawodawca miał na myśli przede wszystkim czynności o charakterze materialno-technicznym, nie zaś oświadczenia woli i wiedzy podmiotów biorących udział w postępowaniu. Pogląd ów można uzasadnić tym, że oświadczenia woli organu, a więc przede wszystkim rozstrzygnięcia kończące bieg postępowania bądź też takie, które mają wpływ na jego bieg (na przykład zawieszenie lub podjęcie zawieszonego postępowania), powinny zaistnieć w określonej, wynikającej wprost z przepisów, formie (decyzji lub postanowienia). Forma ta musi następnie być odzwierciedlona w aktach administracyjnych (przybrać postać dokumentu „papierowego" lub elektronicznego). Postać papierowa to albo pismo zawierające owe rozstrzygnięcie, albo protokół sporządzony zgodnie z zasadami opisanymi w art. 68 k.p.a. Co więcej, przepis art. $67 \S 2$ pkt 5 k.p.a., jako jedną z obligatoryjnych sytuacji, w których sporządza się protokół, przewiduje ustne ogłoszenie decyzji lub postanowienia. Wydaje się, że wskazany przepis stanowi lex specialis względem ogólnej zasady pisemności (art. $14 \S 1$ k.p.a.) i wyjątków od niej przewidzianych (art. $14 \S 2$ k.p.a.). To zaś oznacza, że czynność ogłoszenia decyzji lub postanowienia musi być udokumentowana wyłącznie w formie protokołu. A contrario, inne czynności organu mogą być dokumentowane w formie adnotacji urzędowej. To z kolei potwierdza tezę o rozróżnieniu ,załatwienia sprawy” od jej „rozstrzygnięcia”. 
Omawiając telefoniczne załatwienie sprawy administracyjnej, nie da się uniknąć rozważenia kwestii rodzajów spraw załatwianych tą drogą. Ponieważ, jak już wspomniano, samo pojęcie załatwienia sprawy ma bardzo szeroki zakres, można przyjąć, że obejmować będzie kilka rodzajów czynności. Dla lepszego zilustrowania tej problematyki optymalne wydaje się zastosowanie kryterium podmiotowego jako najbardziej uniwersalnego i czytelnego. $\mathrm{W}$ toku postępowania można więc wyodrębnić:

- czynności dokonywane ze stroną,

- czynności załatwiane $\mathrm{z}$ innymi podmiotami biorącymi udział w postępowaniu (świadkowie, biegli),

- czynności z podmiotami, które nie biorą udziału w postępowaniu, lecz posiadane przez nie informacje są niezbędne do jego biegu (Policja, Służba Więzienna, kierownicy USC, spółdzielnie mieszkaniowe i inni).

Do czynności załatwianych ze stroną, do których może być użyty kontakt telefoniczny, należą przede wszystkim wszelkiego rodzaju powiadomienia (na przykład o możliwości zapoznania się z materiałem dowodowym — art. 79a § 1, o terminie oględzin — art. $79 \S 1$ k.p.a.), jak również wezwania do uzupełnienia braków formalnych (art. $64 \S 2$ k.p.a., wezwanie do wyrażenia zgody na przeprowadzenie mediacji - art. $96 \mathrm{~b} \S 3$ k.p.a.).

$\mathrm{Z}$ kolei do drugiej kategorii można zaliczyć wszelkiego rodzaju wezwania osób biorących udział w postępowaniu (na przykład wezwanie świadków lub biegłego na rozprawę - art. $90 \S 2$ pkt 2 k.p.a.) czy też wezwanie potencjalnych spadkobierców zmarłej strony postępowania do udziału w nim (art. 97 § pkt 1 k.p.a.).

Trzecim rodzajem czynności organu są interakcje z innymi organami, instytucjami lub podmiotami, które dysponują informacjami mogącymi mieć istotny wpływ na wynik postępowania. Zbiorczo można je określić mianem współdziałania, a normatywną podstawę do ich dokonywania stanowi art. 7b k.p.a. Przyglądając się im bliżej, można wyodrębnić współdziałanie formalne i nieformalne. Współdziałanie formalne ma miejsce wówczas, gdy z konkretnego przepisu wynika nałożony na organ prowadzący postępowanie obowiązek zasięgnięcia opinii lub uzyskania stanowiska (w formie uzgodnienia) ${ }^{20}$. Pomijając kwestię rozróżnienia między opinią a uzgodnieniem, dla omawianego zagadnienia istotne znaczenie ma kwestia, czy w ramach współdziałania formalnego możliwe jest porozumiewanie się organów telefonicznie ${ }^{21}$. Otóż wydaje się, że nie ma tego rodzaju przeszkód, z tym tylko zastrzeżeniem, że stanowisko organu współdziałającego winno przybrać postać pisemną. Wniosek taki płynie bowiem z faktu, że ma ono charakter kształtujący wynik postępowania administracyjnego, a wobec tego trudno tu mówić o możliwości odnotowania treści oświadczenia woli innego organu w formie adnotacji urzędowej, pomijając już tylko to, że co do zasady uzgodnie-

20 Por. B. Dobkowska, K. Klonowski, Uzgodnienie projektu decyzji o warunkach zabudowy i zagospodarowania terenu, „Przegląd Prawa Publicznego” 2013, nr 9, s. 35.

${ }^{21}$ Por. K. Strzępek, Współdziałanie organów w stosowaniu prawa, ZNSA 2010, nr 4, s. 64. 
nie przybiera postać postanowienia, co wyklucza utrwalenie jego treści w formie adnotacji urzędowej.

Ze współdziałaniem materialnym można natomiast się zetknąć wówczas, gdy żaden przepis prawa materialnego nie wymaga uzyskania stanowiska innego organu przez organ prowadzący postępowanie. Niemniej jednak potrzeba wyjaśnienia okoliczności faktycznych prawnych sprawy wymaga uzyskania informacji, którymi organ ów nie dysponuje. Tego rodzaju współdziałanie jest spełnieniem postulatu zawartego w art. 7 k.p.a., zgodnie z którym na organie ciąży obowiązek podjęcia wszelkich kroków zmierzających do poczynienia ustaleń pozwalających na załatwienie sprawy.

Powołane trzy typy relacji między organem a różnymi podmiotami biorącymi udział w postępowaniu co prawda nie wyczerpują wszelkich możliwych stanów, jakie mogą pojawić się na gruncie konkretnego postępowania, niemniej jednak dają pewien obraz sytuacji, w których możliwe jest skorzystanie z ułatwień, jakie stwarza komunikacja telefoniczna. Kwestią otwartą jest jednak skuteczność czynności dokonanej przez organ za pomocą telefonu w ramach załatwiania sprawy. Rozważyć bowiem trzeba dwie sytuacje:

— taką, w której organ dokonał czynności, lecz jej przebiegu ani też treści nie zarejestrował $\mathrm{w}$ formie adnotacji, o której mowa w art. $14 \S 2$ k.p.a.,

— taką, w której czynność została dokonana i sporządzono na tę okoliczność adnotację, jednakże nie została ona podpisana przez stronę.

Rozpatrując pierwszy przypadek, stwierdzić wypada, że skuteczność czynności dokonanej telefonicznie (na przykład wezwania strony do uzupełnienia braku formalnego) jest uzależniona od tego, czy strona się do niej zastosuje. Innymi słowy reakcja strony na kontakt telefoniczny, nawet wówczas gdy adnotacja urzędowa nie została sporządzona, sanuje ów brak i czyni działania organu skutecznymi, wywołując zarazem określone następstwa procesowe. Natomiast jeżeli telefoniczne załatwienie sprawy nie zostało potwierdzone adnotacją urzędową podpisaną przez stronę i strona nie zareagowała na telefoniczny kontakt $\mathrm{z}$ organem, jego czynność traktuje się jako nieistniejącą (non existens). Bez znaczenia będzie wówczas powoływanie się przez organ chociażby na bilingi rozmów telefonicznych, uprawdopodabniające kontakt ze stroną. Na podstawie uzyskanych w ten sposób informacji można jedynie potwierdzić fakt przeprowadzenia rozmowy telefonicznej, nie zaś jej treść. Tymczasem zasadniczą funkcją omawianej adnotacji jest właśnie odzwierciedlenie (udokumentowanie) złożonych w trakcie takiej rozmowy oświadczeń wiedzy lub woli.

W drugiej sytuacji organ podejmuje działania telefonicznie, nawiązuje kontakt ze stroną, sporządza adnotację, niemniej jednak adnotacja ta nie zostaje podpisana przez stronę. Pod znakiem zapytania postawić można wówczas nie tylko formalną komplementarność adnotacji, lecz także skuteczność samej czynności. Mając na względzie z jednej strony treść art. $14 \S 2$ k.p.a., z drugiej natomiast art. $72 \S 1$ k.p.a., uważam, że tego rodzaju adnotacja (podpisana przez pracownika organu, 
który dokonał czynności) pełni swoją funkcję — dokumentu potwierdzającego dokonanie czynności. Nie może natomiast grać roli dowodu w postępowaniu, tak jak oczekiwać tego można by od adnotacji podpisanej przez stronę. Wydaje się bowiem, że ów podpis strony na adnotacji urzędowej, wymagany przecież expressis verbis art. $14 \S 2$ k.p.a., pełni funkcję zbliżoną do tej, jaką ma podpis strony na protokole z czynności organu. Przez jego złożenie strona niejako potwierdza nie tylko sam fakt dokonania czynności drogą telefoniczną, lecz również jej treść. Można ją, z dużą ostrożnością, porównać do potwierdzenia odbioru korespondencji kierowanej do strony. Tym samym owa adnotacja powinna być traktowana jak dowód w postępowaniu — stosownie do treści art. $75 \S 1$ k.p.a. Z kolei adnotacja pozbawiona podpisu strony ma słabszą moc dowodową, jednakże brak ów nie czyni czynności dokonanej telefonicznie bezskuteczną. Wypada się zgodzić ze stanowiskiem, że nie jest to dokument służący merytorycznemu wyjaśnieniu sprawy i nie może być on traktowany jako ,pełnoprawny” dowód ${ }^{22}$. Nie można jednak zarazem całkowicie pominąć jego treści i istnienia, choć niewątpliwie będzie to okoliczność stosunkowo łatwa do obalenia przez stronę. Tu jednak powstają wątpliwości, czy te zastrzeżenia odnoszą się do wszystkich trzech opisanych typów relacji telefonicznych, czy tylko do niektórych. Wydaje się, że nie ma podstaw do oczekiwania, że ważność adnotacji sporządzonej przez organ z telefonicznej rozmowy z innym organem, albo z biegłym, wymaga potwierdzenia podpisem strony. Trudno byłoby dostrzec jakiekolwiek uzasadnienie takiego rozumienia analizowanego przepisu. Wydaje się więc, że norma art. $14 \S 2$ k.p.a. w części, w której wskazuje na obowiązek sporządzenia adnotacji urzędowej potwierdzonej podpisem strony, odnosi się tylko do telefonicznego załatwienia sprawy (tych czynności) z udziałem tej ostatniej lub innego podmiotu (organizacji społecznej, prokuratora lub Rzecznika Praw Obywatelskich), który brał udział w postępowaniu na prawach strony.

Z omawianą problematyką wiąże się kwestia „nakłonienia” strony do podpisania adnotacji urzędowej. Skoro, jak już wspomniano, podpis ów uwiarygadnia treść adnotacji i wywołuje określone następstwa procesowe, a zarazem sporządzenie i podpisanie adnotacji następuje już po dokonaniu czynności w ramach „załatwienia sprawy”, to rozważyć trzeba, czy organ dysponuje jakimikolwiek instrumentami pozwalającymi wyegzekwować od strony działanie w tym zakresie.

$\mathrm{Z}$ pewnością nie można tu stosować wprost art. $64 \S 2$ k.p.a. ani też sięgać po niego w drodze analogii. Jest to uzasadnione tym, że po pierwsze, przepis ów stosuje się do podań, a więc pism wszczynających postępowanie administracyjne. $\mathrm{W}$ analizowanym przypadku niewątpliwie nie mamy do czynienia $\mathrm{z}$ tego rodzaju pismem. Po wtóre, adnotacja urzędowa jest wytworem organu, a konkretnie jego pracownika, stąd też bezpodstawne byłoby nałożenie na stronę obowiązku jej uzupełnienia, skoro to nie strona jest inicjatorem jej powstania. Wśród przepisów k.p.a. brakuje jakiejkolwiek regulacji, która umożliwiałaby rozwiązanie tego pro-

22 Por. wyrok WSA w Lublinie z dnia 1 kwietnia 2020 r., III SA/Lu 561/19. 
blemu. Wydaje się, że podpisanie adnotacji o telefonicznym załatwieniu sprawy przez stronę jest uzależnione wyłącznie od jej dobrej woli i nie ma żadnego środka pozwalającego do tego stronę ,przymusić”.

Odrębnym zagadnieniem jest kwestia komunikacji ze stroną za pomocą SMS (Short Message System), a więc krótkiej wiadomości tekstowej przesyłanej za pomocą komórkowego aparatu telefonicznego. Przesłanie stronie postępowania tego rodzaju wiadomości mieści się w pojęciu telefonicznego załatwienia sprawy i jest to, z punktu widzenia art. $14 \S 2$ k.p.a, dopuszczalne ${ }^{23}$. Ten rodzaj kontaktu ze stroną ma tę „przewage" nad zwykłą komunikacją telefoniczną, że treść takiej wiadomości jest archiwizowana w pamięci telefonu, $\mathrm{z}$ którego ją wysłano. To z kolei, w zdecydowanie dalej idący sposób, uwiarygodnia adnotację urzędową sporządzoną po tego rodzaju komunikacji ze stroną. Uważam, że dla celów dowodowych należałoby postulować w tym przypadku praktykę dołączania do adnotacji wydruku przesłanej informacji bądź też fotografii jej treści w telefonie, z którego ją wysłano.

\section{PODSUMOWANIE}

Poczynione uwagi pozwalają stwierdzić, że stworzenie możliwości telefonicznego załatwienia sprawy należy postrzegać jako krok w kierunku odformalizowania postępowania administracyjnego. Oceniając przyjęte rozwiązanie w kategoriach aksjologicznych, wypada je zaaprobować, gdyż wychodzi ono naprzeciw społecznym oczekiwaniom „odbiurokratyzowania” procesu administracyjnego. Daje bowiem organowi narzędzia do zdecydowanie bardziej elastycznego kształtowania przebiegu przynajmniej części czynności procesowych, a uczestnikom tego postępowania poczucie, że administracja znalazła się „bliżej ludzi”. Te pozytywne aspekty omawianej regulacji nie mogą jednak przesłonić pewnych jej mankamentów, które mogą sprawiać trudność w jej praktycznym zastosowaniu. Należy do nich przede wszystkim kwestia prawidłowego dokumentowania czynności podejmowanych $w$ ramach telefonicznego załatwiania sprawy administracyjnej. Chodzi tu w szczególności o podpis strony pod adnotacją sporządzoną przez urzędnika oraz wątpliwości dotyczące ewentualnego braku tegoż podpisu. Kwestią wtórną, lecz związaną z tym zagadnieniem, jest stworzenie kolejnego rodzaju czynności w postępowaniu, co może rodzić wątpliwości odnośnie do jednolitości systemowej przepisów (adnotacja zwykła, adnotacja z podpisem strony). Niemniej jednak uważam, że przyjęte rozwiązanie normatywne należy postrzegać pozytywnie, oczekując zarazem rozwiania sygnalizowanych wątpliwości na drodze nowelizacji bądź też praktyki orzeczniczej.

23 Podobnie Kodeks postępowania administracyjnego. Komentarz, red. M. Jaśkowska, A. Wróbel, Warszawa 2020, s. 159. 


\section{THELEPHONE SETTLEMENT OF AN ADMINISTRATIVE MATTER}

\section{Summary}

The possibility of settling an administrative case by telephone is a significant novelty among the adopted solutions regarding administrative procedures. The legislator considered this issue to be particularly important, creating such a possibility among the general principles of the Code of Administrative Procedure. In practice, however, problems may arise with the application of this provision, especially with regard to its hypothesis and documenting the organ's activity in this regard. This study is an attempt to signal the most important problems that may arise in practice, at the same time indicating the potential possibilities of solving them, and contributes to discussions in this area.

Keywords: handling the case by telephone, official endorsement, contact with the party

\section{BIBLIOGRAFIA}

Adamiak B., Borkowski J., Postępowanie administracyjne i sadowoadministracyjne, Warszawa 2014. Agopszowicz A., Lipowicz I., Glosa do wyroku NSA z dnia 19 stycznia 1995, sygn. I SA 1326/93, „Glosa” 1996, nr 1.

Dawidowicz W., Nauka prawa administracyjnego. Zarys wyktadu, t. 1, Warszawa 1965.

Dobkowska B., Klonowski K., Uzgodnienie projektu decyzji o warunkach zabudowy i zagospodarowania terenu, „Przegląd Prawa Publicznego” 2013, nr 9.

Jaroszyński A., Wplyw przekształceń administracji socjalistycznej na pozycję prawna obywatela, Warszawa 1977.

Kędziora R., Kodeks postępowania administracyjnego. Komentarz, Warszawa 2014.

Kmieciak Z., Ogólne zasady prawa i postępowania administracyjnego, Warszawa 2000.

Kodeks posteppowania administracyjnego. Komentarz, red. H. Knysiak-Molczyk, Warszawa 2015.

Kodeks postepowania administracyjnego. Komentarz, red. M. Jaśkowska, A. Wróbel Warszawa 2020.

Kodeks postępowania administracyjnego. Komentarz, red. Z. Kmieciak, W. Chróścielewski, Warszawa 2019.

Krzykowski P., Funkcje zasad ogólnych Kodeksu postępowania administracyjnego, [w:] Kodyfikacja postepowania administracyjnego na 50-lecie KPA, red. J. Niczyporuk, Lublin 2010.

Leszczyński L., Zasady prawa - założenia podstawowe, [w:] Zasady prawa $w$ strukturze systemu prawa. Studium dogmatyczno-porównawcze, red. L. Leszczyński (,Studia Iuridica Lublinensis" nr 1), Lublin 2016.

Leszczyński L., Maroń G., Zasady prawa. Ujęcie dogmatyczno-porównawcze, [w:] Zasady prawa w strukturze systemu prawa. Studium dogmatyczno-porównawcze, red. L. Leszczyński („Studia Iuridica Lublinensis" nr 1), Lublin 2016.

Rozmaryn S., O zasadach ogólnych kodeksu postępowania administracyjnego, PiP 1959, nr 4.

Starościak J., Studia z teorii prawa administracyjnego, Wrocław 1967.

Strzępek K., Współdziałanie organów w stosowaniu prawa, ZNSA 2010, nr 4.

Wiktorowska A., Zasady ogólne KPA, OMT 1979, nr 4. 


\section{ORZECZENIA SĄDÓW}

(wszystkie pochodzą z bazy orzeczeń sądów administracyjnych, www.nsa.gov.pl/orzeczenia)

Uchwała siedmiu sędziów NSA z dnia 5 grudnia 2011, II OPS 1/11, ONSAiWSA 2012, nr 2. Wyrok WSA w Białymstoku z dnia 16 stycznia 2020 r., II SA/Bk 719/20.

Wyrok WSA w Kielcach z dnia 9 lipca 2020 r., I SA/Ke 166/20.

Wyrok WSA w Lublinie z dnia 1 kwietnia 2020 r., III SA/Lu 561/19.

Wyrok WSA w Rzeszowie z dnia 17 lipca 2019 r., II SA/Rz 544/19.

Wyrok WSA w Warszawie z dnia 29 marca 2006 r., VI SA/Wa 2401/05. 